\title{
Ideology of the Indian National Congress: Political Economy of Socialism and Socialistic Pattern of Society
}

\author{
Md. Ayub Mallick
}

\begin{abstract}
India under Congress regime and others also has not yet attained positive response from its explicit concern for socialistic pattern of society under the grab of mixed economy and liberal-democratic socialism. As a government the Congress creates certain socio-economic situation, which the Congress as a party has failed to cope with. On the other, certain socio-economic and socio-political constraints have made the Congress both as a party and as a government quite unresponsive to the demands of the people. The social and economic reforms remained unimplemented.
\end{abstract}

As a product of French Enlightenment and closely related with the liberation struggle of the bourgeoisie against the feudal onslaughts, the concept of ideology emerged as a science of politics, i.e., a scientific and critical outlook about politics and society. There are different views on ideology. According to Drucker, "To Marxists "ideology" is any theory which guides or acts effectively in the interests of the bourgeoisie. To Liberals, any theory is ideological if it teaches of other theories. To Conservatives, the hallmark of an ideology is an attempt to impose a rational systematic plan on society.' (Drucker, 1974:140).

Marx proposes to depict ideology in terms of hard social realities and its contradictory and conflicting character sprouted from the dialectical relations between forces of production and relations of production and contending character of classes, i.e., in Medieval ages between free men and slaves and in our times between bourgeoisie and proletariat. That is consciousness in human kind emerges from the material conditions of human life. Each new class in society requires to project its own interests as common interests of all, rationally and universally accepted which negates contradictions and legitimates domination. Therefore, the logic is: ideology is cultural domination. Culture is determined by ruling class interest. Therefore, ideology captures culture and culture is determined by ideology. Necessarily likely, ideology legitimizes social structure and the indispensable class formations. Therefore, cultural craftsmanship is the indispensable qualification for working class's revolutionary upsurge as tough fibrous tissue joining muscle to bone.

Critics find a gap in Marx's understanding of ideology. Sartre finds no solution in Marx's materialist understanding of individuals and the conception of individual personality development through regular production process. To Althusser, ideology has a place in reality and there is no ideology except by the subjects and for the subjects (Althusser, 1984: 44). Irrespective of social parentage, according to Marx, ideology has to be understood in association with the contradictions of society and class origin. And for that Gramsci and Lukacs find glaring misconception of ideology in Marx. Lukacs finds that ideology does not and cannot be the necessary reflection of the economy and revolutionary change of a society invites both consciousness and force. To Gramsci, ideology is a super-structural, a 'historical bloc' emanated from the contradictory relations of production and the necessity of lacerated human society. He repudiates the necessary superstructure of a particular structure of base, the arbitrary elucubration of particular individuals and gives primacy to ideological hegemony than that of class hegemony or force. While criticizing Marxian concept of ideology, Freud says that ideology is not only the reflection of the material life processes in society, but of the psychological characters and traits. Pareto absolutizes ideology as psychological instrument of governance by which elites take sociopolitical measures, justified and promoted by idiosyncrasy and idolized by ideologues. Durkheim criticizes Marx of reducing consciousness as a mere epiphenomenon of its basis. He finds consciousness, as collective idiosyncrasy is collective experience. Unlike Marx, Mannheim pointed out that ideologies are not pure illusions, but it is a science of logic and ideas and a taxonomic system of concepts.

Apart from these differences there are some common grounds between Marxism and Liberalism, where both elites hide their real power and intensions by pointing at collective entities and overemphasizing other centers of power to saddleback their accountabilities and responsibilities by adducing 'intense pressure' or 'furious lobbying' or 'suffocating government regulation' or 'bureaucratic red tape' as instances (Beardsley, 1981: 161).

Therefore, ideologies are like looking glasses. It legitimizes political formula. To Mosca, class or so to say political class will always try to justify its power on the ground of ideology, and abstraction, which we shall call political formula (Bluhm, 1974: 13). As per with Pareto's 'derivations' and Sorel's 'myth', ideology is the 
systematic exploitation of beliefs and ideals carefully churned out of men's consciousness with great ingenuity, self-control and courage for fulfillment or near fulfillment of personal or group interests. It rarely justifies the pursuit of interests common to all the groups (Plamenatz, 1970:131). Inspite of that, ideology has a considerable impact on the demands made by the party's supporting centers and groups. It legitimizes power and hides the real contradictions in society. To Poulantzas, 'ideology has the precise function of hiding the real contradictions and of reconstituting on an imaginary level, a relatively coherent discourse which serves as the horizon of agents' experience...' (Larrain, 1979: 46). Ideology is the systematic scheme and process of ideas about social, economic and political life processes of society, which political parties adhere to and proceed on their voyage; a bundle of distinct and unambiguous ideas and creeds, makes for unity and cohesion within the party and brings the party members under the control of their own parties, for example, the 'programmes' and 'mandates'.

Having come into existence at the mid-day on Monday, December 28, 1885, the Indian National Congress with emerging elites of middle class intellectuals propounded their theory about peaceful political action and public protest. In a society with multifarious religious and cultural manifestations, ethnic diversities and economic higher-ups and lower-downs echelon, it was a pluralist, flexible and open-ended organization, once a movement, able to continue in power and simultaneously able to snuff out unprincipled factions upholding at least twin objectives at that time: to arouse nationalism among the Indians and to make India a united nation.

In search for truth and 'Swaraj' from Raj, Gandhi preached the gospel of non-violence and class harmony. And Nehru and other Congress leaders declared that the Congress was to be turned into an electoral organization or into a party to win electoral battles and sit on the saddle of power or at least into a Gandhian organ of constructive programme, i.e., transition from movement to a party or from mass politics to elite politics. Thus pragmatism or 'real politik' began to replace the ideals of socialism, truth and non-violence and watered down Marxism into a milk-water Fabianism. 'As the dominant party, the Congress attracts many Indians who have hardly any ideological affinity to it but want to use the organization as a stepping stone to public offices... Congress has become fully immobile in the trial of its reconciling image as a "movement of social reconstruction" with the task of a political party.' (Hartmann, 1977:52-56). Radicalism and pragmatism were well-balanced (Aggarwala and Aggarwala, 1985:54) as the expedient manipulation of middle class nationalism and democratic socialism.

After Independence, the change in the character of the Congress from a party fighting for freedom to an enthroned party on power seat charged with the constitutional responsibility for political development, economic regeneration and cultural advancement began to take place by a solemn public act. Nehru did not agree to take Congress as mere electoral organization into account. But leaders of Congress did not take any recourse to such action and were unable to do so because the party attracted many new members no longer moved by any idealistic reason but were primarily concerned with power and patronage (Hartmann, 1977: 56). Therefore, Congress leaders followed a middle-of-the-road policy. For that reason Congress party followed the formula of 'socialistic pattern of society' in the Avadi Session (1955) and later on 'Socialist State based on Parliamentary Democracy' in the Bhubaneshwar Session (1968), which were not possible in our socio-economic set-up. And so, besides consensus on 'fundamental norms of the democratic set-up' (Tilak, 1983: 6), a Westminster type of parliamentary set-up cannot be accorded with the possibility of happenings of consensus on specific policies and issues unlike the totalitarian state-building with a monolithic structure in the process where dissension and disobedience are prohibited in full swing. In spite of that as we have accepted the parliamentary practice of British origin, so we should have a responsible opposition with a responsible government in the House and rules of the game, the Congress Legislative Party (I) leader posited (Abedin, 1986). To him, the leader of the House acts as the leader of his own party, as a representative of the whole House and is responsible to the House in general and to opposition in particular; and with an intuitive instinct should be able to measure the troubles brewing and the blazes of commotion. The Congress party, apart from these, accepted the other rules and principles of parliamentary democracy as the political superstructure of our society, for example, representative institutions based on majority rule, limitations on the power of the government, accountability of the government to the electorate, freedom of expression and independent judiciary, multi-party democratic setup with free and fair election. Therefore, the tests for a political system claiming to be based on parliamentary or liberal democracy will, therefore, seem to be the extent to which the government truly represents the mass of the society and the extent to which rights which individuals claim to have are protected (Derbyshire and Derbyshire, 1991: 33), which believes to be put forwarded by the Congress party conveniently.

If the government takes coercive measures, then it is the duty of the opposition to save democracy from the onslaughts of dictatorial measures in terms of thorough public protest within the framework of parliamentary democracy and regulations of parliamentarianism, legal and constitutional guarantees. But Congress leaders from the very beginning believe that peaceful demonstration of grievances and expression of feeling is permissible in parliamentary democracy. But when any government is out to destroy the values and norms of parliamentary democracy needs to be replaced by direct action even under parliamentary democracy, which is essentially a rule of law. For Congress leader, Y. V. Chavan, struggle against unemployment, against economic 
measures which increasingly lower down the condition of living of the masses, and against exploitation and pauperization of man by man on the basis of ownership of the means of production, is protected and defended by coercive apparatuses of the state should not take the form of direct action. This policy approach is nothing, but only to perpetuate bourgeois or capitalist domination in India. Rajni Kothari in his article 'Direct Action - A Pattern of Political Behaviour' finds that Direct Action is inevitable under parliamentary democracy as 'it is difficult to obtain conditions under which the need for direct action is wholly removed. This is not because the people are not mature. Nor would it suffice to say that parliamentary institutions have not taken root in our country. It is really because it follows from the very nature of parliamentary government. It is democracy which gives rise to certain deep-rooted expectations; but the fact is that the democracy is parliamentary, frustrates these very expectations. The conflict between promise and possibility is latest all the time. In times of strain it comes out in the open. The result is Direct Action.' (Desai, 1975: 100). Congress constitution stipulates only 'parliamentary democracy' as the type of polity, which the party is to pursue, i.e., well-being and advancement of the people and the establishment of India by peaceful and constitutional means and of socialist state based on parliamentary democracy (Correspondent, 1984: 1). This socialism is to be achieved through peaceful and constitutional means (Kaushik, 1964: 13). Therefore, Congress constitution bars change in the poor men's polity. Continuous assimilation of differing ideologies in the Congress fold has produced a highly flexible and unidentifiable ideology, from 'everything to everybody' (Misra, 1976: 85). Therefore, the roots of party decay lie in the thought structure of its membership. 'The fog surrounding the mind of a community may well conceal the valley of its self-destruction.' (Dhebar, 1956: 85). The party has been 'overshadowed by the Government' (Palmer and Tinker, 1959: 130) based on a haphazard mixture of Gandhism, socialism and capitalism and to be recuperated by constructive works. But when it does represent westernized leadership essentially committed to take into account state power for a programme of articulating national unity and modernizing the social and economic structure, the right-minded groups are reluctant 'to use state powers in all cases for such purposes' (Weiner, 1959: 25). And for that reason, public sector undertakings have become more expensive than private sector undertakings; economic growth and rationality dwindled or so to say partly fulfilled lagging behind the expectations of our people. In fact, 'poor has become poorer', 'rich has become richer' and 'this makes socialist pattern of society more of a myth than a reality' (Hartmann, 1977: 58).

The casual and vague pronouncements of democratic socialism, the so-called socialistic pattern of society on the one hand, and lack of programmatic directions and substantial theoretical understanding on the other, make room for Congress leaders to have their faith in political personalities much more than ideological commitment and policy orientations. To mobilize the initiative and consciousness of the masses in socialist direction, to enthuse and get their conscious co-operation 'it is necessary to tell them about the task, about how they are to be accomplished and about the difficulties that stand in the way' (Ghosh, 1974: 155). Gandhi himself places importance to the people when he says that true democracy cannot be worked out by twenty men sitting at the center, it has to be worked out by the people at the grassroots level and the success of democracy lies in the success of economic planning and village panchayats (Agarwal, 1954: 4). Therefore, political freedom without economic and social freedom remains a 'vacant dream' (Agarwal, 154: 4). Land reforms should be followed by industrial reforms, i.e., growth of agriculture and the development of industry should be more balanced and the rate of labour absorption must be higher than the rate of population growth to get out of the Malthusian trap in order to set economic equality and social justice into motion. That is why General Secretary of the Indian National Trade Union Congress, K. P. Thripathi says that where human labour should be utilized, the money capital should not be (Thripathi, 1954: 11). It is the way to preserve political stability and democracy, society's essential economic and institutional features; to change the living patterns and habits, fashions and fads of society with 'coat and necktie mentality', 'silk and chiffon', 'sloth and luxury' (Nehru, 1954: cover page); and to build society with honoured persons who work hard, live in simple manner and identify themselves with poorest of the poor. Following the Karachi Resolution, I can say in a plaintive cry that confiscation of private property and class war are contrary to Congress creed of non-violence and class harmony, which is rollicking with healthier relationship between capital and labour.

To ensure a healthier relationship between capital and labour, it envisages appropriate administrative and organizational changes for efficient functioning of industries in the public sector, and that taxation should be so devised as to aim at lessening disparities in income and increase the resources available for development. Again, the decisive turn in Indian social history can be brought about through science, which has played an increasing part in influencing and moulding human life and will do even more in the future. Revolutionary changes in society can be brought about through modernized agriculture on big farms instead of present-day cultivation with primitive technique on pitiably small- holding, universal literacy and rural industrialization etc. By the very nature of the Indian situation and because of teachings of Gandhi and Nehru, the socialist content took a deep turn, which found its organizational expression with the formation of Congress Socialist Party in 1934, and later on an ideological clarification and position through the Congress Forum for Socialist Action (Malavyia, 1983: 17). But 'the directions the Congress has set for the country and which the country is now 
following is the right one, but the advance towards socialism has to be stepped up if the Congress is to escape the fate of being submerged by reactionaries within it.' (Narayanan, 1981: 10). Therefore, in order to come by a socio-economic revolution in our thoughts and ideas and to organize themselves into " "study groups" for successfully fighting the reactionary forces at all levels' (Agarwal, 1953: 4), it is necessary to provide flesh, blood and spirit to Congress organization, to devote considerable time and energy to serious ideological problems, like land reform, industrialization, co-operative farming etc. Far reaching socio-economic changes can be brought about speedily and effectively by peaceful and democratic means. A socialistic pattern of society means a society of just economic and social order based on equality and justice, decentralized economy in the form of small and cottage industries, decentralized political power in the form of village panchayats and state ownership of the means of production with equitable distribution of national wealth, sizeable reduction of disparities, cultural and moral standards, and without exploitation for political and other ends. It is socialism for Sarvodaya Society, 'Ethical Socialism' for decentralized economy and composite democracy, co-operative commonwealth of a socialized economy transited from an acquisitive one, and welfare state for authoritarian safeguards to trample down the evil designs (Agarwal, 1955: 1-4 and 96-99). Prime Minister Nehru recites, 'We fought for freedom and won it. We are the children of that revolution. But that revolution is not yet over. We shall continue it. We finished it in the political sphere but we have to continue it in the social and economic sphere.' (Agarwal, 1955: 20).

Therefore, the Congress ideology most extremely tries to build a state based on democratic constitution and to change society from above; to further the economic interests of the capitalists and to legitimize state by nation-building and national integration; to undertake programmes for relatively independent capitalist development through planning and to enthuse public sector especially in heavy and basic industries. And in agriculture, 'capitalist growth was gradually imposed from above through land reforms and rural development.' (Mukherjee, 1989: 101).

Therefore, it is socialism of a new type, accommodative and agglomerative, more close to romanticism and Catholicism, less to specificity and differentiation and pragmatic to Indian economic conditions, which designed to 'reduce the accumulation of wealth in private hands, and to accelerate the process of industrialization, a large number of essential industries involving hundreds of crores of investments were started by the State.' (Sahni, 1980: 37). In fact, it is a belief in and a value structure about the social ownership of the means of production, distribution and exchange. The most equitable distribution thereof may be possible upon the basis of common ownership of the means of production and the best obtainable system of popular administration and control of industry and services (Rush, 1981: 90-91). Therefore, it is organized revolution, but not violent one, based on liberal democracy, but not proletarian dictatorship, and achieved by persuasion, but not by force. It means the growth of society, the growth of all classes, but not the uprising of any particular class, where the conceptions of right and wrong are common to all. Violent methods are wrong, unparliamentary and must be parliamentary as such. Society must be viewed in terms of social facts, facts of unity, but not class struggle in a jubilant mood. Therefore, parliament is the representative of the common interests of consumers in society, guardian of social order and peace, where social revolution or social and political emancipation of the masses will be achieved by the gradual acquisition of political power by democracy and gradual transformation of society by parliamentary socialism (Miliband, 1961).

The main planks of Congress socialism are based on the same footing, i.e., 'socialistic pattern of society'. It stands for mixed economy and envisages a much more dominant role for the public sector, but allows the important role for the private sector if it becomes consistent wi5th social objectives. It promises to nationalize banks and insurance companies, to curb monopoly and concentration of wealth (Kausik, 1985: 484), in association with abolition of human miseries, employment to the unemployed and radical agrarian reforms programme. Committed to progressive economic policy, Indira Gandhi's 20-point Economic Programme, for instance, measures to bring about maximum production and distribution, liberalization of investment, socialization of urban lands and to bring down prices of essential commodities and over all human sufferings by and through parliamentary legislations. The Congress Party Election Manifesto, 1977 clearly points out: 'The motto of the Congress is: poverty must go, disparity must diminish and injustice must end ... reflecting the vision of Mahatma Gandhi and Jawaharlal Nehru.' (Indian National Congress, 1977 Election Manifesto of the Congress Party, 1978: 133). In its 1979 Election Manifesto, the Congress aims at creating an investment climate in order to improve production, 'formulating a rational income policy and restructuring of the tax system to reduce the burden of the middle classes' (Day and Degenhardt, 1984: 157). Therefore, Congress Election Manifesto wants to fulfill its objectives extending from 'upholding the ideals of secularism' to 'consolidating democracy', from 'fighting poverty' to 'achieving all round development of the economy' (Aggarwala and Aggarwala, 1985: 278). Henceforth, emphasis is on more equitable distribution of the fruits of growth. Therefore, Indira Gandhi's socialism, the so-called 'populist socialism' is different from Nehru's liberal democratic socialism and Gandhi's ethical socialism. P. D. Kausik identifies Indira Gandhi's 'populist socialism' with communism, which is not like Nehru's liberal democratic socialism. Indira Gandhi's socialism 
emphasizes social control like that of nationalization of grain trade etc. (Kausik, 1985: 486). P. M. Mammen points out at least twenty one values, for example, social ends political freedom, equality, individualism, humanitarianism, conflict resolution, peaceful development, national interest, economic growth, planning to control, production, pragmatism, practicality, concerned for time, application of science to man's problems, concern for hard work etc. (Mammen, 1990: 137-38). To him, Nehru's speeches were very vague, but intensity scoring was very high. Nehru's value profile is more strong and less specific in character and utterance.

To the Congress the main instrument of economic and social advancement is planned development to safeguard economic independence, to promote self-reliant growth, and to ensure 'equity in reaping the fruits of development' (Indian National Congress, 1989 Election Manifesto of the Indian National Congress: 16). The Congress is also committed to strengthening the productive forces in our society and furthering liberalization and opening up of the Indian economy. 'It urges for the abolition of inter-corporate divided tax, ending the concept of interconnection among MRTP companies and stresses the need for speedy mergers and amalgamations.' (Mishra, 1987: 8). It also gives significant importance in contributing economic growth, which 'needs to be given all incentive at the cost of public exchequer' (Mishra, 1987: 8). The AICC resolution tries to accommodate both the sentiments of socialism and leftism in the party and to democratically reconcile the feuding interests of feudals and capitalists as well as peasants and proletariat. Correspondents of Economic and Political Weekly malignly express:

It is not clear whether the planners can feel a little more assured about their role after the latest demonstrative left-ward lurch by the ruling party. There is no evidence that deeds will follow words in the critical area of resource mobilisation for planned investment according to a socially meaningful order of priorities, let alone advance towards a socialistic order.

'Maximum democracy and Maximum devolution' (Gandhi, 1989) whisper about higher agricultural productivity, remunerative cropping patterns and greater income and employment reciprocally connected with urban ones, but jeopardize the interests of the impoverished ones and push back them to a cold, damp and foggy night and a fouled atmosphere of corruption and sycophancy. But Congress programme says, '...we have to think afresh about our plans and programmes... We have to make new sacrifices.' (Gandhi, 1988). But how much and how long? - this question remains unanswered.

Congress ideology can be equated with Thatcherism in the West, but 'Indian Thatcherites do not say an outright no to planning; they say yes to somewhat less to planning' (Vanaik, 1990: 56) which aims at 'creating a privileged nation which lives in constant (but hopefully always manageable) tension with a less privileged one' (Vanaik, 1990: 56). An eminent political scientist, Sudipta Kaviraj finds a coalition, a tidy tying-up of dominant interests of the industrial bourgeoisie and rich peasantry and an administrative and professional elites operated through 'one-party dominance system' to improve structural constraints on policy making and policy implementation. Emphasis was paid more on production than distribution headed by bourgeois state hegemony. The post-independent state mechanism with greater autonomy like that of Bonapartist or Bismarckian pattern desires to see labour classes to be contended within the framework of the existing relations of production, and attacks the concentration of wealth while making room for private ownership of the means of production (Sen, 1982: 207-8).

Therefore, the Congress ideology is a great deceiver determined by factors generated from the depths of society, i.e., society with gradual enrichment of the capitalist class at the cost of public sector, aggravating inequalities in distributing wealth and income, and increasing proletarianization of the masses within the "matrix of the exploitative-capitalist system' (Desai, 1984: 149). Though the Congress emphasized the equitable wage and income policy based on need-based wages and reduction of monstrous disparity in income of big capitalists, landlords and masses (Mehrotra, 1980: 59), there was really a political ploy to deprive the disadvantaged poor for the benefit of the advantaged haves. In India's multi-structured pluralist society 'gaps' are created between promises and performances by powerful forces of change in society. Marc Galanter finds that politicians make the promises of socialism, and then give or provide less change than that of the required change by maintaining proper distance. Legal measures are inadequate to cross or comprehend this distance (Galanter, 1992: XXIIIXXIV). Unsurprisingly, Congress ideology and ideologues have created an illusion, an appearance of socialism, and not a reality of anti-monopoly and anti-landlord measures in the minds of the 'very classes and strata against whom they were opposed to be directed' (Namboodiripad, 1974: 39). They have not yet pointed to the concept of 'socialism' particularly, but merely reflected an image of a 'socialist' society without any particular specification of the idea of social justice, except the assurance of 'no intention of abolishing the institution of private property' (Ghurye, 1978: 12), and capitalist development of Indian society (Bharater Chhatra Parishad, 1986: 40). By and large, from its very inception Congress had been a magnificent umbrella organization with so many groups and opinions as to produce it a convenient problem shooter to all sections and shades of people, from one extreme to another. Burdened with no 'isms', except 'self-ism', Mrs. Gandhi's leadership was immensely suited and conveniently manifested to cut much ice from the slogans of socialism or capitalism or 
others in the deep and dark. Therefore, Congress ideology is: democracy and socialism in the wind and power in the mind. And Nehru's ideology was less specific.

Nehru reminded the task of India in the ending of poverty and ignorance and inequality of opportunity, and in asserting the basic human capabilities and quality of life in the success of socio-economic policies and in promoting economic growth of the country and quality of life of the people. 'Basic education, good health, and other human attainments are not only directly valuable as constituent elements of our basic capabilities, these capabilities can also help in generating economic success of a more standard kind, which in turn can contribute to enhancing the quality of life even more. Many of the ingredients of a good quality of life - including education, health, and elementary freedoms - clearly do have instrumental roles in making more productive and helping us to generate more inputs and incomes.' (Sen, 1996: 6). Nehru particularly stressed on socialistic pattern of society for the development of India, where public attention and activism would be the ultimate guarantee of governmental initiative and action in a country like India where democracy has become the order of political life. However, ever since 1937 Nehru neglected the grassroots organization and relied on elections and intensive campaigning, which found its cogent expression in 1967, especially in 1969 when the conflict between parliamentary and organizational wings became unbridgeable and unresolved. The Congress leaders were not able 'to utilize the party as a tool of direct politicization and social transformation' (Kohli, 1987: 69) and to utilize the government machineries to implement Central policies and programmes at all levels. Paul Sweezy justifies this democratic-capitalist framework in terms of ownership of the means of production owned by the few, separation of the total means of production into competing units and production of goods and services by the workers owing no ownership of the means of production, but only to sell their labour to the owners in order to take the bare necessities of life and a small part of the mixed of production (Shakir, 1986: 42). The 'mixed economy' policy was adopted only to divert the goals of socialism in a planned and regulated manner, and agrarian legislations were passed only to reduce the glaring inequalities so that any revolutionary outbursts could not take place. As agrarian bourgeoisie and rural influentials were most powerful in mobilizing the poor and the downtrodden vis-à-vis the industrial ones; the 1951-55 and 1956-60 policies were the reflections of the relative unity between state elites and rural and urban bourgeoisie, so the Congress leaders did not and could not make institutional changes in agriculture. The leaders provided distribution of patronage and spoils in exchange of electoral support. But with the rapid development of pro-poor politics of urban bourgeoisie, the rural counterpart feared for status insecurity and veered round the consumerist culture of urban middle class to get 'benefit from the agriculture, and to enter the expanding small scale industrial sector, whether agro-based or not' (Vanaik, 1990: 28). Therefore, the Congress leaders pursued a two-pronged strategy: growth before distribution and industrialization in the context of popular welfares and socialism. In fact, liberaldemocratic forms exert conservatizing pressures. Adam Przeworski (1980) and Claus Offe (1985) necessarily emphasize electoral necessity to produce pluralities and thereby downplay class appeals. Social democratic parties have abandoned radical goals in favour of a reformist approach in order to represent themselves and appear politically responsible as well as capable of delivering immediate material benefits. Przeworski says that to win the votes of people other than workers, particularly the petty bourgeoisie, to form alliances and coalitions, to administer the government in the interests of the downtrodden sections and working classes, a party, a social-democratic party cannot act like an 'irresponsible' or to give an indication of being less than interested about its commitment to the rules and limits of parliamentary game (Przeworski, 1980: 30-31). Indian National Congress itself as a centrist party has pursued and is now pursuing social-democratic policies like that of a social-democratic party. The New Times Soviet journal evaluated that the prestige and status of the Congress party had declined considerably due to the 'capitalist path of development, which India has followed since liberation, has not imported the lot of the people' (Nayar, 1969: 127). Ever since Independence Congress politics was mainly an urban politics with only few exceptions of Gandhian politics, receiving supports from the upper echelons of the society and providing benefits and opportunities to them. It was politics of a 'long way from the top of the Indian society to the bottom' (Banerjee, 1974: 16). In this context, I support the simultaneous operation and development of 'growth' and 'distribution' which the economic policies of the Congress leaders towards socialism and socialistic pattern of society did not pursue and whatever pursued was opposite to intensive agricultural development and employment generation in effect, on the one hand, and socialism and socialistic pattern of society, on the other hand. Therefore, 'It retards production, limits employment and is oriented in favour of urban areas, heavy industry and organized labour at the cost of small industry, agriculture, rural areas and vast majority of the unorganized labour force and consumers in general. Therefore, this socialism is the negation of real welfare or 'Janakalyan' of the people.' (Madhok, 1972: 18).

Despite the declaration of socialism in government and society, the progress and development were minimal, when, the nationalization programme was downgraded by private sector undertakings to avoid radical changes in the socio-political structure. Citation here may be made that there are three basic causes of slow growth in industrial sector in spite of more capital accumulation and more savings for investment, which may be stated as inefficiency in state-controlled economy, low aggregate demand, declining public investments and 
infrastructural bottlenecks (Ahluwalia, 1985; Chakravarty, 1984; and Bardhan, 1984). Devoid of any ideological commitment and moral integrity, the Congress culture is power culture and its leadership is the prisoner of the country's body politik, when mere generational change might not solve the intergenerational problems and satisfy the true needs of democracy: integration of values and ideas, beefing up liberty, equality and social justice, integration of democratic institutions like parliament, judiciary, bureaucracy and political parties, and a federative-decentralized power drive etc. Essentially,

The Congress culture pervades Indian politics, it can be found not only in opposition bourgeois parties but also in the Marxist left. The Indian middle class loves the Congress because it does not require it to make hard choice, because its concept of socialism doesn't mean distribution of wealth but only its acquisition.... (Sen Gupta, 1988: 765).

Congress leaders with their extra-ordinary powers both in the government and party have had extended their tentacles of domination over their subject people in a calculated way with the help of party cadres, ranks and files, and thereby lost the power exertion and assertion, and integration between elite and mass, or in a Weberian style of politics the relative equilibrium between authority and consent. The Congress leaders seemed to be incapable of responding to the growing needs of the people. It lost the minimum consensus for conflict resolution and goal achievement to maintain social order based on collective interests and Rousseauvian 'General Will' satisfying the common purposes and liquidating the severe and unprecedented hardships generated from price hikes, non-availability of essential commodities, corruption, nepotism and social security problems like malnutrition, illiteracy etc. It was socialism for personal gains, for 'people with influence in local power centers, usually with land and connections among relatives and fellow-caste men who had land, lent money and could muster clout.' (Manor, 1982: 101). The leaders did not follow the 'common approach' (Rastogi, 1980: 339) for dealing with major questions of economic, social and political importance, had to contest for loaves and fishes in downgrading the liberal pursuits with a socialist breakthrough and the establishment of a socialistic pattern of society.

Congress made no systematic attempt to develop the economic conditions. Fifty per cent of the population has been living below poverty line. Diversion of resources took place for the benefit of the privileged sector. The per capita national income at 1960-61 prices marginally declined by 0.4 per cent from Rs. 351.8 (1970-71) to Rs. 350.2 (1971-72). The per capita national income at 1960-61 prices in 1972-73 was estimated to be Rs. 337.6. It was 3.6 per cent fall over 0.4 per cent fall in 1971-72. The per capita income at constant prices at Rs. 347.2 in 1973-74 jumped by 2.8 per cent over 1972-73. The per capita income at 1960-61 prices for 197475 was estimated to be Rs. 341.4. It was a fall of 1.7 per cent over the year, 1973-74.At the constant (1960-61) prices the per capita income for 1975-76 was estimated to be Rs. 365.9. It was the rise of 6.6 per cent over the previous year, 1974-75. Again, the per capita income at 1970-71 prices was estimated at Rs. 653 for the year, 1976-77. It was a decline of nearly 0.7 per cent over that in the previous year, 1975-76. In 1977-78 it rose upto Rs. 695 and in 1978-79 it was estimated to be Rs. 714.6, and declined to Rs. 662.5 in 1979-80 reflecting a fall of nearly 7.2 per cent over the previous year. Per capita NNP (Net National Product) shot upto 8.6 per cent in 1980-81 and 1981-82, i.e., from Rs. 662.5 in 1979-80 to Rs. 719.9 in 1981-82 (Ghosh, 1984: 216-17). Economic development in terms of industrial production, wholesale prices of all commodities, capital expenditure of the government during 1952-84 fluctuated throughout the years. Average annual growth rate in foodgrain production increased from 4.49 per cent during 1952-63 to 4.5 per cent to 8.04 per cent during 1976-77 and 1980-84. Economic development was unstable and unable to make a breakthrough (Table No. 1 and Figure No. 1). Huge population was in the dark. Political and administrative elites were unmindful to the needs and requirements of the socialistic pattern of society. Conflict between privileged and underprivileged sections of the society developed and with this 'the urban-based middle classes were able to co-opt the other entrenched interests into their own framework and the hiatus between the haves and have-nots became complete.' (Kothari, 1976: 21). To Manor, the emergence of the power groups made an adequate situation to the collapse of the old transitional system, i.e., the privileged and powerful groups for their own interests and continuance of dominance narrowed down the principle of representation, wrecked the old machine politics for the interests of the urban industrial groups and middle class, sapped the vitality of the rural influential in order to banish another power center as a champion of the interests of the poorer sections of the society. Mrs. Gandhi and other leaders appeared to have abandoned the principle of representation and the hope of strong and transactional organizations only to gain narrow personal advantages in the power game (Manor, 1982: 105).

The privileged and powerful seemed to have fear about the growing dissatisfaction of the rural havenots and depressed mass, and the probable emergence of rural leaders to lead the depressed class from the rural influential groups. Therefore, the powerful groups displaced a two-pronged strategy: tight control over representation and organization, on the one hand, and relatively uncontentious and anodyne commitments to recuperate from underdevelopment, to raise the down-trodden above the Poverty Line, to distribute benefits and largesse to the rural poor, to remove rural poverty, to generate employment and encourage self-reliant economic growth in a total neglect of balanced economic growth, on the other hand. Agricultural and public sectors were 
in the interest of industrial and private sectors. Agricultural sectors were neglected in comparison with other sectors like industry, manufacturing and services. Capital-intensive technologies reduced rural employment and agricultural labourers were displaced to other sectors, despite the employment generation caused by credit and extension services and power and transport infrastructures. Rural unemployment and underemployment remain high in India with the higher growth in population. Rural employment may grow faster if there are sufficient conditions for improvement: growth in demand for farm employment and more labour-intensive technologies, fisheries and forestry. But India lacks sufficient diversification of rural occupational structure (Weiner, 1989: 119). According to Amartya Sen, market inequalities certainly do make unequalizing influences on the Indian society as these have been done by public sector inefficiency and trade restrictions. Trade liberalization with labour-intensive activities may have an inequality reducing influence. Market-oriented reforms may have produced economic achievement rather than that of inherited and ascribed status. If market-oriented reforms involve only de-regulation and leaving the things to the market, then these reforms may harm the distributional effects; but if market-oriented reforms justify strong emphasis on promoting labour-intensive economic activity, on making use of resources to expand public services, on enabling the disadvantaged groups to participate in the process of economic growth and on expanding and improving social security arrangements, then these reforms will make a real opportunity to achieve as well as to reduce poverty. Public works programmes will play a positive role in addressing social security problem. The economic activities should be support-led instead of purely growth-oriented (Dreze and Sen, 1995).

Though public sector has developed, it has not been able to produce goods for the public, to spread socialism based on social ownership of the means of production and production for the assessed needs of the people and to capture economic and political powers from the capitalist-kulak power group. 'In the totality of meager industrial development, capital devoted to production of the means of production in the organized sector was hardly Rs. 825 crores and 63.4 per cent of the fixed capital formation was in the private sector. By 1965-66 the gross fixed capital formation had risen to Rs. 4025 crores, of which 51.7 per cent is now in the public sector. This implies that the public sector has played an increasingly greater role in generating gross fixed capital in the country. This has enabled the private sector, in the context of mixed economy, to generate nearly Rs. 1946 crores worth of gross fixed capital. Thus it is clear that the state, through its public sector, is actively engaged in generating an industrial base for the Indian economy and is taking increasingly responsibility for providing capital goods and is stimulating similar development of producers' goods industries in the private sector.'

(Desai, 1984: 64). In its 1980 election manifesto the Congress party had promised its faith in the mixed economy and resuscitation of the economy making a two-pronged attack in respect of demand and supply to contain price hikes and formulate new policies. The manifesto endorsed the role of public sector in expanding and improving the country's economy with the objectives of installed capacity, maximization of production in higher productivity and employment generation, correction of regional imbalances, development of agro-based industries, new and growing flow of investments in rural and urban industries, and equal opportunities of investments and dispersal of small and growing units (Report, 1980: 10). AICC (I) also endorsed proper and adequate supply of essential commodities by means of well-organized public distribution system, rationing and cordoning system, preventive actions against black-marketers and hoarders, and consumers' protection movement, and represented its 'commitment to curbing monopolies and restrictive practices' and to require that large industrial houses 'be compelled to conform to national priorities' (Editorial, 1983: 5). But the Congress party has failed to halt black money, hoarding and black marketing and taken certain 'explicit programme of goals' and 'a series of officially or unofficially sanctioned safeguards' (Shepperdson and Simmons, 1988: 21) to protect their interest via capitalists and kulaks and minimize the possible dangers to their interests. The social and economic upliftment of the poorer sections of the society was not attained. Though the Congress (I) leadership reiterated the left-of-the-centre posture and condemned the right opposition parties it did not take any positive measure to ensure socialism, to provide opportunities and benefits to the poor farmers, by-passed by the Green Revolution and tenant cultivators were left in the cold. The conditions of the urban and rural poor and also of educated unemployed remained the same as before because of inadequacies of land reforms and industrial development.

Before Independence Congress party included mainly high caste Hindus, intellectuals, teachers and professionals and changed its character as precursor of rural landed interests both at the national and state levels. Hence, the rich and well-to-do farmers had formed the Congress's inner councils both at the central and state levels, influencing policies in their own favour and controlling the local seats of power. The tenants did not get any tangible benefit. Not only the equity and productivity of land, but also 'equality after land reforms' (Lamba and Tomar, 1986: 148) - all are necessary to make a dependable and balanced relation between the masses and the state, and a reasonable balance of power in the rural society. As an empty hypocrisy the principle of socialism heavily loaded with ethical and moral contents has served to mask or sideline the material conditions of the masses and the 'ideology of personal power' (Naik, 1983: 108), which really helps the leaders to hold political power functioning at all levels, brings them into public life, impels them to join the Congress (I). It is 
'....a pseudo-socialist populism has gained ground among the people of the country, promising earth and heaven to the downtrodden.' (Selbourne, 1982: 214). When the Chief Ministers and other inner circle political leaders derived their strength from the land-owning classes, Mrs. Gandhi dragged them down with a call for "Garibi Hatao' and 20-point Economic Programmes in the 'stepped-up sub-Chinese rhetoric about helping the weaker sections, going to the masses, serving the people and the like' (Selbourne, 1982: 77). But the progress of land reforms was little made and 'actual transfers were even more minuscule than before: 2500 hectares nationwide from 1972 to 1975.' (Hart, 1991: 33). The Congress party and government, therefore, had followed a 'democratic-capitalist model of development' (Kohli, 1987: 9) so as to provide redistributive facilities to the lower classes, but not at the cost of lower classes. It was an attempt on the part of the Congress leaders to help the propertied classes and rural elites with its ideological and organizational hegemony.

I stress on urban areas, heavy industry and organized, which was weighted by the Congress leaders as they were tied to urban-industrial bourgeoisie, who were in favour of commercialization of agriculture. Though Mrs. Gandhi promised special programmes for 'harijan' (untouchables), adivasis (tribals), and minority communities who have fallen behind; ... new land legislation would be implemented with the good of the people in mind rather than for private interests.' (Franda, 1973: 215), she drowned in the troubled water of Green Revolution policy and ICC's (Indian Chamber of Commerce) initiative of commercialized agriculture. With the introduction of Green Revolution there emerged surplus of agricultural labour with an increase in foodgrains and pressure on oversaturated lands, which in turn was released to the urban and industrial sectors satisfying the labour needs of the industrialists at low prices. Industries were developed to absorb the huge barefooted and ill-feeded migrants and prevent political upheavals. To prevent future political upheavals, to make an easy access to labour at low prices and increased productivity at low costs, and to run down growing labour disputes, the ICC was against radical agrarian reforms and opted for 'a centralized and coordinated food policy and blamed the states for failing to bring down food prices which was affecting the entire cost structure of the economy.' (Mukherjee, 1985: 116). Suniti Kumar Ghosh found that Indian bourgeoisie was involved in feudal ownership and extraction of rent, and so they were involved in opposing radical land reforms (Ghosh, 1985: 281). Therefore, the Indian bourgeoisie and big business houses had inhibited the independent policy formulations of the Congress party and articulation of group interests.

The business groups contributed large sum of money to the Congress party as a ruling party. The business lobby spreads its tentacles in the organizational and governmental wings of the Congress party, are in search for their policy of political realism without contributing any more to the Congress's policy of socialistic pattern of society, but had given the right to represent their leaders in Parliament, right to organized labour union to the workers and peasants without promising rebellion or revolution. It has suffocated public opinion, so to say vigilant public opinion. The large-scale donations of the big business houses to the Congress party were only for 'the simple reason of adhering to a policy of enlightened pragmatism' (Johari, 1972: 117).

When Indira Gandhi returned to power in 1980 she moved to pragmatism and rightwardness from her earlier anti-poverty rhetoric of 'garabi hatao', which was less ideological as it is compared with her pre-Emergency orientation. However, the rhetoric of socialism and nationalism was maintained, but anti-poverty slogan of 'garibi hatao' was put on the back of queue. An emphasis was made on Hindu chauvinism and communalism, on the more pro-business policy and negotiatory loans from International Monetary Fund or IMF, on liberalization of industrial licensing, and on imports coupled with lowering of import dities and promotion of foreign technical collaboration. Kohli $(1987,1991)$ evaluates that Mrs. Gandhi pursued a pro-business policy leaving aside her socialism.

... her "socialism" was not working. The anti-poverty programs had not been totally successful. Thus, her continuing electoral support among the poor was not due to concrete rewards but rather to her ideological and rhetorical appeal. She believed that she could maintain the rhetoric even while watering down the overall "socialist program". More socialist rhetoric would not have brought her much more political capital in any case; the limits of rhetorical socialism had been reached. She must have calculated that a movement toward liberalizing the economy, while maintaining some rhetoric of socialism' would be likely to strengthen her political base. (Kohli, 1991: 311).

The business groups also indirectly influence the selection of candidates for the election. Business groups confer money in exchange of licenses and permits, and protective decisions with an appeal to personal friendship and favours. They have been benefited through 'contract' businesses from the public sector. The government itself has not wanted to wipe out the private sectors, who have wanted to produce more goods and services and to increase their capital. For example, the balance of power between public and private sectors, governmental units and industrialists, socialist and liberal democratic extremes proves further the democraticcapitalist model of development. Statistically, 'As on $30^{\text {th }}$ September, 1981, 66,632 companies limited by shares with an aggregate paid-up capital of Rs. 15,254.8 crores at work in various states and union territories of India. These companies comprised 867 government companies and 65,765 non-government companies with a paid-up capital of Rs. 11,261.6 crores and Rs. 3,993.2 crores respectively of the companies at work, the great bulk 
consisted of private companies.' (Kamal: 1984: 210). The private concerns were given a complementary role in the Indian mixed economy in the public eyes without making a capital-developing, labour-intensive, employment-generating and land-augmenting capital-formation. The Indian business groups exert heavy pressures on the Congress in the formulation of its policies through its representation in various bodies and committees, control over the press and discussion in parliament and legislative bodies. The government through acts and regulations has improved the conditions of the big business through protective tariffs, tax concessions, financial aid, communication and power facilities, and supply of technical know-how and management of risky fields in terms of low taxation-high profit principle. Therefore, the Congress government was committed to spend on public utilities and services both in agriculture and industry which provided the business groups 'with a constantly expanding home market' guaranteeing 'profitable operations'. (Lamb, 1959: 260-61).

Therefore, the Congress leaders followed the mixed economic model in a planned and controlled manner to enhance the competitive and individual and corporate initiatives, but inefficient state controlled economy, 'low aggregate demand' and 'declining public investments and related infrastructural bottlenecks' (Kohli, 1992: 308) produced heavy dosages of economic and dependent capitalist development. Import liberalization, promotion of foreign collaboration and the on-going financial help from the IMF have created the economy stagnant and dependent. The leaders calculated the costs of socialism and benefits of economic liberalization, making a curious balance between the two, taking the growth-oriented land reforms satisfying the rural gentry and alienating the urban industrialists on the one hand, taking industrialization and commercialization of agriculture satisfying the urban industrialists and alienating the rural influential, on the other hand. The anti-monopoly legislations, nationalization of banks, community development programmes, and poverty alleviation measures produced Mrs. Gandhi's popularity a tool for mobilizing the people and provided Mrs. Gandhi enough political trust and confidence to move the politics of socialism, planning and self-reliance on the stage, and capitalism, state hegemony and indigenous development of capital behind-the-scene. It is the politics of rationalizing of patronage and constraining of demands. The business groups through subtle and notso-subtle means manipulated the tools of Congress party and government. And despite the socialist rhetoric there was growing concentration of commercial and industrial capitals. It may be cited that -

The degree of concentration can be judged by the fact that, in 1951, the twenty richest family groups owned 29 per cent of all private capital, whereas in 1968 the ten top family groups possessed 28 per cent of total private capital. An official survey revealed that, in 1964, seventy-five top business houses, controlling less than 6 per cent of all non-banking farms in the country, owned 47 per cent of total company assets. By 1969, their share had gone up to 54 per cent of the total company assets, with the top twenty houses registering individual gains of 55 per cent to 196 per cent (Hiro, 1978: 110-11).

While population increased by 50 per cent during the period 1951-71, the industrial production index rose by 333 per cent from 54.8 to 180.8 . The production of steel went up from 1.3 million tones in 1955 to 4.6 million tones in 1971, that of cement from 4.6 million tones to 14.9 million tones, soda ash from 79,000 tones to 4,83,000 tones, cotton textiles from 6,278 million metres to 7,356 million metres, and commercial vehicles from 9,500 to 40,800 . The rise in industrial production looks as dramatic as it does partly because the initial base was small and partly because Congress Government has been sincere in its commitment to the policy of rapid industrialization - a concept which has all along had the active support of the Indian businessman - capitalist class ((Hiro, 1978: 105-6).

The Congress (I) leaders, especially under Rajiv regime pursued the policies of deregulation, import liberalization and easy access to foreign technology, which jeopardized independent growth of capitalism and indigenous development of capital. The business groups intended that they were not ready to deal with overall import liberalization and easy access to the multinationals and foreign capitals in Indian market, to compete with foreign business with new technology, as they followed the policy of capital-export and protected domestic market: 'They produce for protected markets, on occasion they wish to improve their technology with imports, and many either are in or would like to enter export markets.' (Kohli, 1992: 326). So, the head of Federation of Indian Chamber of Commerce and Industries, D. H. Panandiker said that even after three decades of highly protective industrialization, the policy of liberalization could not be taken on all fronts. First we had to make domestic competitiveness, then to go the outside world (Kohli, 1992: 328). Rajiv Gandhi during his tenure I office followed a policy of liberal economy sharply deviated from the earlier state-controlled import-substituted model of economy. Secondly, in calculating the economic costs and political gains Rajiv moved to and fro with his earlier liberal standpoint fearing about the loss of political popularity and electoral decline. Thirdly, for that, Rajiv Gandhi did not take any positive policy pursuit in spite of the proposed and committed economic liberalization. Rajiv Gandhi made shift from Nehru and Indira's recalcitrance to a more accommodating and compromising set of policies of socialism, planning and self-reliance to a set of subtle and judicious combination of deregulation, liberalization and easy entry of foreign technology and capital into Indian market. Rajiv's inexperience contributed to his popular belief that major policy changes would make his impression greater and provocative. The state under Rajiv regime stood as autonomous, free from all societal imperatives 
and free to impose economic rationality from the above, and to pursue the ideological whims of the powerful leaders and elites. The word of 'socialism' was not contained in the budget speech of 1985-86. However, there was controversy within the Congress over the policy changes from socialism and as a result of that government continued to push a bit of liberalizing reforms. Hence, Congress's commitment to socialism put emphasis on the government's economic policies would also make continuity with the past on the ground that socialism would define the limits, which new policies would have to fit. These definitions of limits of socialism would be flexible to fit to the new policy changes under Rajiv regime (All India Congress Committee-I, 1985). The government under Rajiv regime tried to make reconciliation between liberalism and socialism, to emphasize greater importance to growth with social justice, equity, and eradication of poverty and self-reliant economic growth with import of foreign technology. Naturally, mixed-economy model was once again reiterated by the government. The approaches to liberalization and socialism were basically halfhearted. Therefore, Congress government was not socialist government or capitalist government as such. Establishment of a socialistic pattern of society was not established firmly. Oscar Lange finds that a socialist government really intent upon has to carry out its socialization programme at one stroke. The coming into power of such a government with socialism as its ideology and content must either guarantee the immunity of private property and private enterprise to function normally or it must go through socialist programme at maximum speed. Any hesitation or any vacillation or indecision would provoke economic crisis and breakdown of economic growth. Socialism is not an economic policy for the timid. Any to and fro movement between extremes and position at the middle of the two would make socio-economic development a Herculean task. A government attuned to socialism must formulate and implement labour plan to attack unemployment and economic depression. If the labour plan is carried out successfully, the popularity of the socialists will be increased. Unfortunately, India has had not a labour plan as such. But even a socialist government whose purposes are confined within the limits of such a labour plan needs bold decision in carrying out its programme, and if it is not with such, it will be degenerated into a mere administrator of the existing capitalist society (Lange and Taylor, 1976).

Here, I stress on Lange and Taylor's concept of popularity of the socialist government. And in view of popularity Congress government did not pursue acceptance either of liberalization of the economy or of socialism. Trade liberalization and protected domestic market were taken for granted in order to secure popular support of big business houses and industrialists, where mere eyewash approach to poverty eradication and social justice did not produce fruitful results. The emphasis on technology and efficiency appealed to the business section's preference for results over ideology, though controversy between traditional and modern business houses appeared on the issue of foreign technology. International competition within Indian economy was being fostered. Urban middle classes provided support for Rajiv Gandhi on account of westernized culture punctuated by technology, computers, efficiency and lavish life style. Consumerism was protected by the state. However, within the Congress party controversy over development strategy took a serious turn culminating in the reaffirmation of the old development strategy of self-reliance and socialism and in continuity with the past. This was done in view of the loss of electoral and political support among the masses and rank and file of the party activists, respectively. Economic liberalization, deregulation and opening up the economy to foreign multinationals, and import of foreign technology were not doing well with the party workers at the grassroots level, who had to face recurrent grievances from the down-trodden sections of the society worried by the problems of food, cloth and shelter. The left forces protested against the policy approach to liberal, deregularized economy and 'strike was organized mainly around political demands: halting the policy of privatization, stopping the flow of foreign and national private capital into public-sector activities, protecting domestic good against imports, and ensuring the right of trade unions to have a voice in deciding technological changes,...' (Kohli, 1991: 335). Rajiv, then, pushed back his pro-rich image in putting the economic reforms on the back- bench in order to build electoral majorities and popular support in favour of his party. The left in India stressed on radical land reforms as strategy of planned development instead of monopoly capitalism and industrialization. Patnaik remarks that -

India's progress in the direction of liberalization has been slow and halting because of domestic opposition. But the effect of even this progress in increasing poverty has created a degree of disillusionment with liberalization. And this creates the conditions for the introduction of an alternative trajectory, altogether different from the dirigiste and liberalization trajectories, involving a different role of the state, sustained by a different class configuration and a different economic programme. This programme though bourgeoisdemocratic in character, would be in opposition to the hegemony of imperialism, and hence would have to be based on a mobilization of the workers and peasants.... Instead of the strategy of "international export-led industrialization", the alternative strategy would emphasize "internal export-led industrialization", i.e., industrialization sustained by exports from industry to an agriculture growing rapidly on the basis of radical land redistribution. (Patnaik, : 154).

Though the Congress leaders conceded to their demands, the Indian businessmen and bourgeoisie did not recover from the onslaughts of imperialism and the trap of foreign capital, and thereby could not gain their 
independent development. Ever since Independence, the native industrial monopolists formed a holly alliance between domestic merchant capital and foreign enterprise to maintain the existing socio-political structure and to develop a national bourgeois state in India. The Indian bourgeoisie was antagonistic to both imperialism and mass revolution, so they followed the middle-of-the-road-policy: compromise with the imperialist forces in order to halt further violent upsurge and maintain the fertile ground of inequality and exploitation for the development of a national bourgeois state under their leadership. And the Indian National Congress, as a multiclass organization added fuel to the flames and was busy with its determination and drive. After the transfer of power the Indian capitalists surrendered to the imperialist capital. The Congress party declared that Government should allow the entry of foreign capital for the country's economic development, to supplement Indian enterprise but should be regulated in the national interest and the interests of the bourgeoisie. 'Foreign collaboration to them started to mean additional financial resources, advanced technology, highly developed marketing organization, the prestige of foreign brand-names and personal prestige and advantages.' (Ghosh, 1985: 277-78).

To protect the interests of the big business, the state under the control of Congress leaders controls the policies and choices through incentives and sanctions, interests and actions of the organized groups, and their organizational and group behaviour in our pluralist market society, and regulates 'the internal affairs and external conduct of business, trade unions and other organizations' (Kochanek, 1974: 65-66). In essence, political parties control and dominate the trade union activities, and exploit trade unions in their own political ends. Therefore, trade unions are weak, and if it wants to become strong, it must be independent and out of parties' control. To Morris, '... political use of the trade union movement has led the Congress governments increasingly to use state power to discipline labour and to regulate its welfare;' (Morris, 1959: 268) as the social and economic conditions of the workers are weak to lead the organization, and their commitments to organize action are not conducive to trade union militancy or its role as a political party or pressure group as in the West. One authority has produced an analogy between political parties and trade unions, taking the former as 'holding' or 'parent' companies and the latter as 'subsidiaries', when left unions are 'wholly owned subsidiaries' and Congress or right unions are subsidiaries with some autonomy (Sengupta, 1977: 65-66).

Therefore, trade unions had been able to mount a defensive against the centrist politics of the Congress leaders and their affiliated INTUC, even with some autonomy, but not conducive to independent trade union movement. The leaders most systematically and ruthlessly had subverted the organized movement through coercive measures in spite of labour's participation and co-operation in the management of industry and openended collective bargaining systems. The government had adopted procedural measures of bargaining, shifting its attention from unskilled labour to skilled labour, white-collared professional workers, and thereby giving the industrialists and businessmen enough opportunities to flourish in the absence of weak bargaining agents, prominence of restraints on strikes and 'manipulation of diverse and divided unions to assure acceptable representation and favourable policy and dispute outcomes' (Rudolph and Rudolph, 1987: 280). The Congress leaders have pursued the policy of compromise and regulated conflict to make the capitalist success a sure.

In the rural areas, Congress is supported by landlords, traders and moneylenders, and in the urban areas, by industrialists and business, despite its commitment to democratic socialism. Therefore, to ensure this it supports the passive trade union movement and a disciplined working class. Ever since Independence, the Indian national Congress has followed the passive revolutionary path accompanied by the Gandhian principle of self-suffering and non-violence in tune with the self-satisfaction and gratification of the interests of the Indian big bourgeoisie and feudal elements. In fact, it was a bourgeois movement detriment to the interests of the working class and the peasants. The national movement can be equipped with 'a bourgeois movement, as its very name implies and its objective so far has been, not a change of social order, but political independence' (Lieten, 1988: 80). And it still continues now, though the INTUC accepts the principle of socialism and industry under national control and ownership. INTUC toes the paths followed by the Congress leaders and the measures of land reforms, labour legislations, nationalization of banks and insurance companies thereby. In its 1962 report, INTUC general secretary continued, 'during the two terms of its regime, the policies followed by the Indian National Congress and its Government at the Centre and the States occasionally did cause some dissatisfaction and hardships and at times by not fully rising up to the expectations of the people, but on the whole its policies led the country to political stability and fostering economic progress.' (Crouch, 1966: 126). Therefore, INTUC was eager to establish an order of society with all round development of individual personality free from inequality and exploitation; to ensure full employment and better living conditions, participation of the workers in the management of industry and labour, various measures of social securities for the workers; and lastly to secure better industrial relations: redress of grievances through negotiation, conciliation, arbitration and adjudication (if arbitration fails, then strike or other forms of struggle may be applied, but within the limits of legitimate methods), sense of responsibility to the industry and standard of efficiency and discipline. For example, to ensure better industrial relations the Government promulgated MISA to prevent bandhs and strikes in various industrial establishments as being opposed to interests of the workers and the country as a whole, when they are 
resorted to either for political reasons, or for exploiting the sufferings and sentiments of the people. Before the promulgation of MISA by Indian Government, the General Council of INTUC at its meeting in May, 1967 appealed to the workers that legitimate trade union activity and constitutional trade union methods were necessary for progress and development of economy and industry and condemned 'gheraos as a malafide trade union method and added that they could not be tolerated in a democratic society ... unless the threat of gheraos was effectively checked, it would prove harmful to planned progress of the nation, labour and industries.' (Ramanujam, 1986:263). Hence, INTUC concentrated its attention to the interests of the industrialists: maintenance of law and order, police verifications in cases of unlawful actions and legitimate labour movements, left aside its careful attention to the causes of gherao: non-implementation of laws, awards, contracts (11 per cent); loss of retrenchment, lay off, discharge and redundancy (12 per cent); union recognition (3 per cent); disciplinary action, charge sheet etc. (14 per cent); increase in wages, allowances and interim relief (17 per cent); arrears of wages ( 7 per cent); bonus and profit sharing (13 per cent); others ( 9 per cent); and not known ( 9 per cent). Out of 96 per cent of the total gheraos conducted, 62 per cent responsibility went to the AITUC, 12 per cent to the INTUC, 6 per cent to the UTUC and 4 per cent to the HMS (Vaid, n.d.: 33 ). Therefore, INTUC was least interested in workers' movement. I argue that industrial peace is duly responsible for economic development and national progress of the country, but not at the costs of the workers, the feelings, emotions of the people and community values prevalent in the society. Efficient and honest implementation of labour legislation and administration of labour laws should be made associated with deep-rooted social consciousness and greater social responsibility. With regard to the administration of labour laws, the Constitution itself safeguards the central government to impose severe restrictions and duties on the state governments, whatever may be their party-brands; and also provides the supremacy of laws enacted by the Parliament over the laws passed by the state legislatures:

Articles 256 and 257 of the Constitution authorize the Central Government to give necessary directions to the State Governments in order to ensure compliance with laws enacted by Parliament. Article 258 authorizes the Central Government to confer powers and to impose duties upon the State Governments or their officers in respect of laws made by Parliament (Vaid, 1965: 10).

Therefore, the Congress party had virtually controlled the growing labour unrest by means of labour laws and other authoritarian measures. Trade union activity has become the sediment of industrial relations in India, lying between the two extremes: communistic trade unionism and bourgeois trade unionism. The leaders hoped to regulate industrial relations through the mitigation of the causes of conflict by means of voluntarily accepted codes of conduct, rules of regulations and statutes, co-operation between union leaders and the dialogue between government, union leaders and the employers. The employers exploited the divisive elements of caste, religion and language and applied the familiar method of divide and rule, often encouraged rival trade unions to compete with one another. The laws were enacted to protect the interests of the employers, where the '.. the labour force, by and large, attained a sufficient degree of permanence and regularity' (Mamkootam, 1982: 112). Therefore, 'external leadership, including interference, multiple unionism, union rivalry, compulsory adjudication and arbitration instead of collective bargaining, and low literacy rate among the workers, are some of the commonly attributed factors responsible for the weakness of the trade union movement in India.' (Mamkootam, 1982: 109). Hence, the Congress and INTUC leaders had attempted to develop paternalism and trade unionism. In the underdeveloped country like India, the trade unions cannot develop a legitimate and stable trade unionism due to economic dislocations, social differentiations and political fragmentations, as 'a system of interest representation in which there is an unlimited number of multiple and voluntary, non-hierarchical and self-determined groups not legitimate but tolerated, ... in which the state may intervene to augment or restrict particular groups in legal/non-legal and overt/covert ways.' (Chatterjee, 1980: 8). Therefore, it is the Indian variant of democratic trade unionism perpetrated by authoritarian or dictatorial trends.

Out of the two models of development, i.e. the capitalist model of development and its socialist counter part, when the former separates state, market and civil society and the latter makes a fusion of these three. The capitalist model of development takes the state as the agency of coercion and power, market as the arena of economic activity motivated by material incentives and regulated by market mechanism, and civil society as the space for free voluntary activity. In socialist model of development the party controlled state regulates both the market and civil society. India follows the middle path between the two models of development, where there is a combination of multi-party democracy, planned economy and state intervention. However, despite India's emphasis on economic development and distributive justice, inequality between the rich and the poor, and the population below the poverty line have increased. At this point, liberalization of the economy was introduced conceding autonomy to the market economy, which now is being eroded by foreign market. India started out in the 1950s with high rates of growth, open trade and investment, an interventionist state, awareness about social expenditure on social security arrangements, removal of poverty with growth-oriented approach, macroeconomic stability etc. and ended with low growth rates, closure to trade and investment, restrictive state, 
inability to sustain social expenditures, low efficacy of growth in reducing poverty, macro instability and crisis etc. in the 1980s. In 1991 economic reforms were made and New Economic Policy was introduced. The policy features of the New Economic Policy stressed on delicensing of industries, removal of the ceiling on production capacity of industries, policy of broad-banding, import-substitution, foreign collaboration, expansion of private sector and larger market orientation. Thereby, the ideology of socialism was downgraded. Then, the civil society has to fight the two fronts, the state and the market. 'Commercialization and the greater play of market forces typically operate to increase economic inequalities, and the reduction of "welfare" activities of the developmental state which could, to some extent, have mitigated the harsher aspects of such a process are inhibited by the stabilization and structural adjustment which are part of this paradigm.... The growing inequality that is already becoming evident in India is reflected not so much in the narrowing of the category of the "rich" or upper-income groups; indeed, these may possibly increase in absolute numbers due to the proliferation of service sector and other white collar activities that tend to expand in such periods.' (Ghosh, 1997:181). The failure in Indian developmental experience is inevitable and indicative of the fundamental contradictions, which are bound to be developed by the essentially capitalist strategy. The government has failed to ensure a redistribution of productive resources, particularly in the agricultural sector, and to set up an industrial infrastructure. The vast majority of the country's population has no money to buy industrial products. However, the goal should really be to remove poverty, to work towards a non-property society and not towards a consumer oriented, highly industrialized, high energy using society. Amartya Sen (1997) evaluates that except the case of 86 per cent of Kerala, India lags behind China in terms of average level of female literacy (39 per cent $<68$ per cent). Not only that. India is also enormously adverse compared with China in terms of average literacy rate (both male and female combined), life expectancy, infant mortality rate etc. The basic problem is where 'too much' government has been identified in India, there is 'too little' government action in the fields of elementary education, health care, land reforms and social security. Hence, the ideology of sicialism and socialistic pattern of society is not actualized thereby. Further, the market-based economic growth was not ascertained due to lack of social opportunities mentioned above. The state of India could not attain the results neither of a socialistic pattern of society or of a capitalist society. Mention here may be made that the ideology of socialistic pattern of society and the ideology of liberal-capitalist framework were taken for granted by the Congress party and government in order to secure a wider coverage of electoral support for gaining power and seats of power. The journey is a miraculous, indeed. It lacks specificity. Creation and use of social opportunities on a wider scale requires much more than that of de-regulation and liberalization. To ensure sustained growth of a socialistic pattern of society the need is a judicious combination of public action and active public policy, a responsive, but not only responsible government. Congress government did not produce the image like this. Sen finds,

We have to go well beyond liberalization to get somewhere.... There are positive initiatives to be taken for raising the human capabilities that make life worthwhile ... serve as the basis of fast and participatory economic growth.

The radicalism that is needed cannot be met by just removing restraints through deregulation and reform, and it must also embrace the positive duties of responsible government to create social opportunities.

The fundamental changes that are needed in India cannot be met by moderate reforms that only focus on reducing the negative activities of the government, neglecting the positive functions that it can perform on bringing social opportunities within the reach of all.

India under Congress regime and others also has not yet attained positive response from its explicit concern for socialistic pattern of society under the grab of mixed economy and liberal-democratic socialism. What the party and government had done towards socialism was only eyewash with an implicit concern for power drive and an explicit concern for populism. The positive duties with a tone of radicalism are needed for bringing about fundamental changes towards welfare, economic growth, liberal-democratic socialism, and a socialistic pattern of society keeping behind the scene mere moderatism or moderate reforms or middle-of-theroad policy of the government.

As a government the Congress creates certain socio-economic situation, which the Congress as a party has failed to cope with. On the other, certain socio-economic and socio-political constraints have made the Congress both as a party and as a government quite unresponsive to the demands of the people. As to the crisis of bourgeois-landlord system and the transformation of the Congress from movement to party and then to government, the Congress has used repressive measures and manipulated all the state apparatuses to contain pressures and conflicts from below in order to preserve exclusive bourgeois class interests. Though the bourgeois class has adopted the parliamentary mechanism, though the working class has intruded into the system; but has not been able to use it for their own demands and advantages: abolition of bourgeois-landlord system, planned and independent development of national economy, promotion of civil liberties and need-based wages. The social and economic reforms remained unimplemented. The party drew its strength in the rural areas from the dominant elites, and in urban-industrial areas from bureaucrats, businessmen, industrialists and 
professionals. The social situation was not sustained by the twin revolutions of industrialization and democratization, which a parliamentary democracy needed to impart and consolidate the values and norms of democracy. Inequality in access to resources and social positions reinforced social and economic inequalities, which created tensions and gaps at the social level. The slow economic growth and the appropriation of developmental benefits by propertied classes had produced cumulative inequalities and accelerated economic growth was frittered away in maintaining these classes and pampering them by giving them subsidies in one form or the other. Therefore, under the present socio-economic conditions and in the faces of growing frustration, the system lost its legitimacy producing a wide gap between the mission of social transformation of the Congress leaders and the demands and interests of the underprivileged.

\section{Notes and References}

[1]. A Report. 1980. 'Text of Economic Resolution', Economic Times (December 7).

[2]. Abedin, Zainal. 1986. West Bengal Legislative Assembly Proceedings (File No. 18: $1^{\text {st }}$ copy).

[3]. Agarwal, S. N. 1955. Socialistic Pattern of Society (New Delhi: All India Congress Committee).

[4]. Agarwal, S. N. 1955. Towards a Socialist Economy (New Delhi: All India Congress Committee).

[5]. Agarwal. S. N. 1954. 'Bhoodan and Economic Revolution', AICC Economic Review (Vol. VI: No. 1)

[6]. Agarwal. S. N. 1954. 'Economics of Village Panchayats', AICC Economic Review (Vol. VI: No. 2).

[7]. Aggarwala, S. C. and Adish C. Aggarwala. 1985. Legacy of Indira Gandhi (New Delhi: Socialist Age Publications).

[8]. Ahluwalia, I. J. 1985. Industrial Growth in India (Oxford: Oxford University Press).

[9]. All India Congress Committee (I). 1985. Economic Resolution, 1985 (New Delhi).

[10]. Althusser, L. 1984. Essays on Ideology (London: Verso).

[11]. Banerjee, Amritava. 1974. 'India: Social Forces in a Stunted Polity' in Amal Kr. Mukhopadhyay (ed.), Society and Politics in Contemporary India (Calcutta: Council for Political Studies).

[12]. Bardhan, Pranab. 1984. The Political Economy of Development (Oxford: Basil Blackwell)

[13]. Beardsley, Philip L. 1981. Conflicting Ideologies in Political Economy: A Synthesis (London: Sage Publications).

[14]. Bharater Chhatra Parishad [Students' Federation of India] (ed.). 1986. Sanghathita Chhatra Andoloner Panchasbachar: Aethijhya O Uttaradhikar (in Bengali) [Fifty Years of Students' Movement: Tradition and Heritage] (Calcutta: Paschimbanga Rajya Parshad [West Bengal State Committee]).

[15]. Bluhm, William T. 1974. Ideologies and Attitudes: Modern Political Culture (Englewood Cliffs: Prentice-Hall).

[16]. Chakravarty, Sukhamoy. 1984. 'India's development Strategy for the 1980s', Economic and Political Weekly (May 26).

[17]. Chatterjee, Rakhahari. 1980. Unions, Politics and the State (New Delhi: South Asian Publishers Pvt. Ltd.).

[18]. Correspondent. 1984. 'Congress - I constitution bars change in polity', The Statesman (September 2).

[19]. Correspondents. 1985. 'Cheers for Congress Socialism', Economic and Political Weekly (May 11).

[20]. Crouch, Harold. 1966. Trade Unions and Politics in India (Bombay: Manaktalas).

[21]. Day, Alan J. and Henry W. Degenhardt (eds.). 1984. Political Parties of the World (New York: Longman Group Ltd.).

[22]. Derbyshire, J. Denis and Ian Derbyshire. 1991. World Political Systems: An Introduction to Comparative Government (W and R Chambers Ltd.).

[23]. Desai, A. R. 1975. State and Society in India (Bombay: Popular Prakashan).

[24]. Desai, A. R. 1984. India's Path of Development (Bombay: Popular Prakashan).

[25]. Dhebar, U. N. 1956. Presidential Address (Indian National Congress: $61^{\text {st }}$ Session, p. 15), quoted in Ram Sagar Misra, The Congress in Power, p.85.

[26]. Dreze, J. and A. Sen. 1995. India: Economic Development and Social Opportunities (Oxford: Oxford University Press).

[27]. Drucker, H. M. 1974. The Political Uses of Ideology (London: Macmillan Press).

[28]. Editorial. 1983. 'Calcutta Congress', Economic Times (December 30).

[29]. Franda, Marcus F. 1973. 'Radical Politics in West Bengal' in Paul R. Brass and Marcus F. Franda (eds.), Radical Politics in South Asia (Massachusetts: MIT Press)

[30]. Galanter, Marc. 1992. Law and Society in Modern India (New Delhi: Oxford University Press).

[31]. Gandhi, Rajiv. 1988. 'Peoples, Policies and Programmes', Speech made at Kashipur.

[32]. Gandhi, Rajiv. 1989. 'Maximum Democracy and Maximum Devolution', Speech made in Lok Sabha.

[33]. Ghosh, Alak. 1984. Indian Economy (Calcutta: World Press Pvt. Ltd.).

[34]. Ghosh, Jayati. 1997. 'Development Strategy in India: A Political Economy Perspective', Sugata Bose and Ayesha Jalal (eds.), Nationalism, Democracy and Development (New Delhi: Oxford University Press).

[35]. Ghosh, Parimal Chandra. 1974. 'Ideology and Indian Politics' in Amal Kumar Mukhopadhyay (ed.), Society and Politics in Contemporary India (Calcutta: Council for Political Studies).

[36]. Ghosh, Suniti Kumar. 1985. The Indian Big Bourgeoisie (Calcutta: Subarnarekha)

[37]. Ghurye, G. S. 1978. India Recreates Democracy (Bombay: Popular Prakashan).

[38]. Hart, Henry C. 1991. 'Political Leadership in India: Dimensions and Limits' in Atul Kohli (ed.), India's Democracy: An Analysis of Changing State-Society Relations (New Delhi: Orient Longman).

[39]. Hartmann, Horst. 1977. Political Parties in India (Meerut: Meenakshi Prakashan).

[40]. Hiro, Dilip. 1978. Inside India Today (London: Routledge and Kegan Paul).

[41]. Indian National Congress (I). 1989. Election Manifesto of 1989.

[42]. Indian National Congress (I). 1978. 'The Congress Party Manifesto, 1977' in Myron Weiner, India at the Polls: The Parliamentary Election of 1977 (Washington: American Enterprise Institute of Public Policy Research).

[43]. Johari, J. C. 1972. 'Organized Business and Indian Stasiology' in Indian Parties and Politics (ed.) (Simla: Institute of Constitutional and Parliamentary Studies).

[44]. Kamal, K. L. 1984. Democratic Politics in India (New Delhi: Wiley Eastern Limited).

[45]. Kaushik, D. P. 1964. 'Bhubneshwar Congress - a New Milestone on Road to Socialism', AICC Economic Resolution (Vol. XV: No. 17).

[46]. Kausik, D. P. 1985. 'Economic Creed of the Post-independent Congress: The Nehru-Indira Phase', The Indian Journal of Political science (Vol. 46: No. 4).

[47]. Kochanek, Stanley A. 1974. Business and Politics in India (California: California University Press). 
[48]. Kohli, Atul. 1987. The State and Poverty in India: Politics of Reform (Cambridge: Cambridge University Press).

[49]. Kohli, Atul. 1991. Democracy and Discontent (Cambridge: Cambridge University Press).

[50]. Kothari, Rajni. 1976. Democratic Polities and Social Change (New Delhi: Allied Publishers).

[51]. Lamb, Helen B. 1959. 'Business Organization and Leadership in India Today' in Park and Tinker (eds.), Leadership and Political Institutions in India (Princeton: Princeton University Press).

[52]. Lamba, S. K. and J. S. Tomar. 1986. Impact of Land Reforms on Rural Development: A Critical Appraisal (New Delhi: Agricole Publishing Academy).

[53]. Lange, Oskar and Fred M. Taylor. 1976. On the Economic Theory of Socialism (New York: Mc-Graw Hill).

[54]. Larrian, Jorge. 1979. The Concept of Ideology (London: Hutchinson and Company Ltd.).

[55]. Leiten, Kristoffel. 1988. 'The Indian National Congress and the Control over Labour: Need for Passive Revolution' in Kapil Kumar (ed.), Congress and Classes: Nationalism, Workers and Peasants (New Delhi: Manohar Publications).

[56]. Madhok, Balraj. 1972. 'Polarization of Like-minded Parties' in Indian Parties and Politics (ed.) (Simla: Institute of Constitutional and Parliamentary Studies).

[57]. Malavyia, H. D. 1983. 'Congress and Nehru's Socialist Vision', Link (December 25).

[58]. Mamkootam, Kuriakose. 1982. Trade Unionism: Myth and Reality (New Delhi: Oxford University Press).

[59]. Mammen, P. M. 1990. 'Content Analysis and a Case Study in Nehru's Value-profile' in V. Grover (ed.), Political Thinkers of Modern India, Vol. 10 (New Delhi: Deep and Deep Publications).

[60]. Manor, james. 1982. 'Dynamics of Political Integration and Disintegration' in A. J. Wilson and Dennis Dalton (eds.), The States of South Asia: Problems of National Integration (New Delhi: Vikas Publishing House).

[61]. Mehrotra, N. C. 1980. Political Crises and Polls in India (New Delhi: Deep and Deep Publications).

[62]. Miliband, Ralph. 1961. Parliamentary Socialism (London: George Allen and Unwin).

[63]. Mishra, Girish. 1987. 'CWC Resolution and Practice', Mainstream (May 30). The author further remarks that the role of public sector investment is to be restricted only to those areas, which can stimulate demands for the private sector. The area of small-scale sector is to be drastically curtailed and the norms of foreign collaboration to be further liberalized and the management of sick industrial units is to be allowed more liberty in downing their shutters and throwing those workers into the street.

[64]. Misra, Ram Sagar. 1976. The Congress in Power (Patna: Jnanada Prakashan).

[65]. Morris, David. 1959. 'Trade Unions and the State' in Park and Tinker (eds.), Leadership and Political Institutions in India (Princeton: Princeton University Press).

[66]. Mukherjee, Sanjeeb. 1985. 'The Bourgeoisie and Politics in West Bengal' in Rakhahari Chatterjee (ed.), Politics in West Bengal (Calcutta: World Press Pvt. Ltd.).

[67]. Mukherjee, Sanjeeb. 1989. 'Class Struggles and the State in India' in Zoya Hasan, S. N. Jha and Rasheeduddin Khan (eds.), The State, Political Processes and Identity: Reflections on Modern India (New Delhi: Sage Publications).

[68]. Naik, J. A. 1983. Opposition in India and the Future of Democracy (New Delhi: S. Chand and Company).

[69]. Namboodiripad, E. M. S. 1974. Conflicts and Crisis (Bombay: Orient Longman).

[70]. Narayanan, Edatata. 1981. 'The Congress and Socialism', Link (September 6).

[71]. Nayar, Kuldip. 1969. Between the Lines (New Delhi: Allied Publishers).

[72]. Nehru, Jawaharlal. 1954. 'Speech delivered at Dalhousie, Punjab', AICC Economic Review (Vol. VI: No. 8).

[73]. Offe, Claus. 1985. Disorganized Capitalism (Massachusetts: MIT Press).

[74]. Palmer, Norman D. and Irene Tinker. 1959. 'Decision-making in the Indian Parliament' in Richard L. Park and I. Tinker (eds.), Leadership and Political Institutions in India (Princeton: Princeton University Press).

[75]. Patnaik, Prabhat. 'The State in India's Economic Development' in Zoya hasan (ed.), Politics and the State in India (New Delhi: Sage Publication).

[76]. Plamenatz, John. 1970. Ideology (London: Macmillan Press). Plamenatz says, 'Political ideology, for all its vagueness, affects people's conceptions of the "common" interests of the groups they belong to, and also (though less directly) their private aims. Even though there is no aim shared by all the supporters of a party other than its getting power, the party's ideology, the principles and sentiments that its leaders proclaim and the more general arguments used to justify its policies, have a considerable influence both on the demands made on the party by the groups that look to it for favours and on personal ambitions.', pp. 131-32.

[77]. Przeworski, Adam. 1980. 'Social Democracy as a Historical Phenomenon', New Left Review (Vol. 122: August-September).

[78]. Ramanujam, G. 1986. Indian Labour Movement (New Delhi: Sterling Publishers Pvt. Ltd.).

[79]. Rastogi, Satish Kumar. 1980. The Congress Crucible: Role of Indian National Congress in Indian Politics (Meerut: Anu Publication).

[80]. Rudolph, L. I. And S. H. Rudolph. 1987. In Pursuit of Lakshmi: The Political Economy of the Indian State (Chicago: Chicago University Press).

[81]. Rush, Michael. 1981. Parliamentary Government in Britain (London: Pitman Books Ltd.)

[82]. Sahni, J. N. 1980. The Lid-Off-Fifty Years of Indian Politics, 1921-71 cited in Satish Kumar rastogi, The Congress Crucible: Role of the Indian National Congress in Indian Politics, 1966-1980 (Meerut: Anu Publications).

[83]. Selbourne, David. 1982. Through the Indian Looking Glass (Bombay: Popular Prakashan).

[84]. Sen Gupta, Bhabani. 1988. 'Crisis of the Indian State', Economic and Political Weekly (April 16).

[85]. Sen, Amartya. 1996. 'Radical needs and Moderate Reforms' in J. Dreze and A. Sen (eds.), Indian Development (Oxford: Oxford University Press).

[86]. Sen, Anupam. 1982. The State, Industrialization and Class Formations in India (London: Routledge and Kegan Paul).

[87]. Sengupta, Anil Kumar. 1977. 'Trade Unions, Politics and the State: A Case from West Bengal', Contributions to Indian Sociology (Vol. 2: No. 1).

[88]. Shakir, Moin. 1986. State and Politics in Contemporary India (New Delhi: Ajanta Publications).

[89]. Shepperdson and Simmons. 1988. The Indian National Congress and the Political Economy of India, 1885-1985.

[90]. Thripathi, K. P. 1954. 'The Controversy of Rationalization', AICC Economic Review (Vol. VI: No. 2).

[91]. Tilak, Raghukul. 1983. 'Conflict and Consensus: Opposition's Democratic Duty', The Statesman (November 12).

[92]. Vaid, K. N. 1965. State and Labour in India (New Delhi: Asia Publishing House).

[93]. Vaid, K. N. n.d. Gheraos and Labour Unrest in West Bengal (New Delhi: Shri Ram Centre for Industrial Relations and Human Resources).

[94]. Vanaik, Achin. 1990. The Painful Transition: Bourgeois Democracy in India (London: Verso).

[95]. Weiner, Myron. 1959. 'Some Hypotheses on Politics of Modernization in India' in Richard L. Park and I. Tinker (eds.), Leadership and Political Institutions in India (Princeton: Princeton University Press).

[96]. Weiner, Myron. 1989. The Indian Paradox (New Delhi: Sage Publications). 


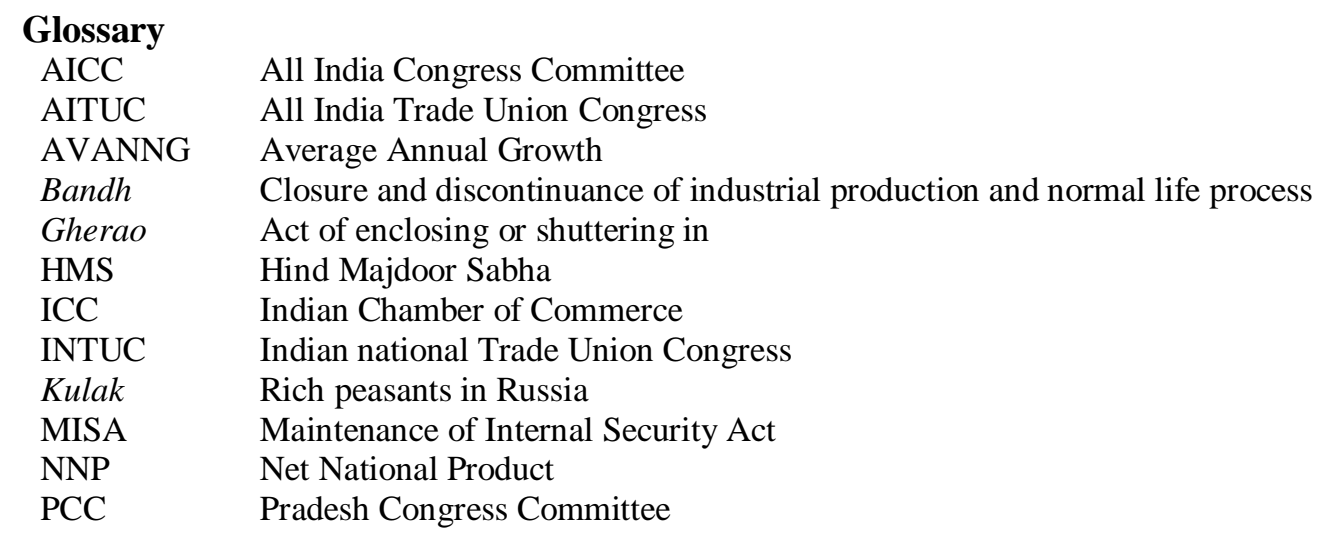

